Article

\title{
Institutional Quality, FDI, and Productivity: A Theoretical Analysis
}

\author{
Jaewon Jung ${ }^{1,2}$ (D) \\ 1 Department of International Trade, Dankook University, Yongin 16890, Korea; jung@dankook.ac.kr \\ 2 THEMA, CY Cergy Paris University, 95011 Cergy, France
}

Received: 29 July 2020; Accepted: 27 August 2020; Published: 29 August 2020

check for updates

\begin{abstract}
While many important links between institutional quality and foreign direct investment (FDI) inflows and/or between inward FDI and economic development through productivity growth have been uncovered, the full links between emerging and advanced economies are not yet well understood. This paper develops a model of FDI with an explicit distinction between the two economies where domestic and multinational firms using different technologies compete on the final good market and highlights the institutional quality-FDI-productivity link within a unified theoretical general equilibrium framework. We show that an improvement of institutional quality in the emerging economies induces pervasive technology-upgrading effects in the advanced economies, which generates aggregate productivity gains.
\end{abstract}

Keywords: institutional quality; foreign direct investment (FDI); productivity; worker and firm heterogeneity; technology upgrading; globalization; emerging and advanced economies; sustainability

\section{Introduction}

Foreign direct investment (FDI) is one of the main driving forces of globalization. It has grown much faster than trade and domestic production during recent decades. In particular, FDI inflows to developing countries have increased much more rapidly than FDI inflows to developed countries. The share of developing countries in worldwide FDI inflows has increased from $25.5 \%$ in $1982-1987$ to $31.1 \%$ in 1994-1999 and accounted for more than 50\% in 2007-2018 [1]. With the rapid increase in FDI flows, there is now a general consensus that inward FDI has been a key factor for economic development of many emerging countries. Not surprisingly, a large part of the literature on economic development has been focused on the determinants of FDI inflows to developing countries, and highlights, among others, the importance of institutional quality to attract FDI.

Consequently, many systematic links between institutional quality and FDI inflows and/or between inward FDI and economic development through productivity growth have been uncovered. There has been abundant empirical evidence showing a positive and significant relationship between institutional quality and FDI inflows. A broad set of institutional variables has been tested and emphasized. For instance, Wei [2] highlights a significantly negative impact of corruption on FDI inflows. In addition to the positive impact of good institutional quality on FDI inflow levels, Buchanan el al. [3] also show that good institutional quality reduces FDI volatility. On the other hand, Benassy-Quere et al. [4] focus on the institutional distance between the source country and the host country and show that institutional distance tends to reduce bilateral FDI. Other studies also discover the importance of property rights to attract FDI (see, e.g., [5-7]). Recent studies also examine the impact of composite measures of institutional quality on FDI: e.g., Gani [8] shows that the rule of law, control of corruption, regulatory quality, government effectiveness and political stability are all positively correlated with FDI; Daude and Stein [9] note that, among various institutional variables, some aspects, such as the unpredictability of laws, regulations and policies, excessive regulatory burden, government instability and a lack of commitment, matter more for 
the location of FDI; moreover, see Jensen [10] for the importance of political factors as determinants of FDI. Another branch of the literature has also largely investigated and identified the positive impact of FDI on economic growth or development (see, e.g., [11-13]).

While many important links have been studied and revealed, however, most studies in the literature have analyzed advanced and emerging economies separately, thereby with limited insights on the full relationship between institutional quality, FDI and productivity. For example, given the close interdependence between emerging and advanced economies in today's globalization process, how an institutional improvement in the emerging economies affects the aggregate productivity of the advanced economies should be of particular interest, and for this we need a unified model incorporating all elements with an explicit distinction between the two economies.

The aim of this paper is to highlight the institutional quality-FDI-productivity link within a unified theoretical general equilibrium framework. For this, we develop a simple model of FDI incorporating the institutional-quality-adjusted FDI costs. For possible analysis of productivity effects, we consider different technologies available for production. Two types of firms-high-tech multinational firms and low-tech domestic firms-coexist and compete on the final good market. There is now ample evidence that more productive firms self-select into export markets and among these the more productive ones become multinationals (see, e.g., [14-18]). High-tech multinational firms engage in FDI and produce intermediate components in the emerging economies with cheaper labor costs, while low-tech domestic firms produce all inputs only domestically.

Existence of heterogeneous firms using different technologies also implies worker-technology assignments in the labor market. For this, this paper develops a Roy-like assignment model [19] in which workers sort into different technologies based on their respective comparative advantage. Since workers are differentiated by their individual skill level and different tasks require different specific technologies, workers' productivity reflects not only their own skill level but also the technology they are using. Thus, the economy-wide labor productivity is determined by equilibrium technology-skill assignment. In this regard, this paper is also closely related to the literature on firm and worker heterogeneity in international trade highlighting the globalization-induced real productivity gains (see, e.g., [20-29]).

Firms engaging in FDI have to incur additional fixed set-up costs to operate in the emerging economies. These FDI costs are highly related to the overall uncertainty level of the host country. Though uncertainty is a very broad concept embracing many different forms, institutional uncertainty (or institutional quality) has been at the center of concerns in the investment decision literature. The possible channels on how institutional quality (or uncertainty) affects FDI are now widely documented. For example, Daude and Stein [9] explain two important channels: poor institutional quality can act like a tax by increasing the cost of doing business, as well as increase uncertainty regarding future revenues. Brunetti and Weder [30] distinguish four categories of uncertainties in the institutional framework-government instability, political violence, policy uncertainty, and enforcement uncertainty-and show that institutional uncertainties are indeed important for cross-country differences in aggregate investment rates. In a similar vein, recent work by Julio and Yook [31] also highlight that political uncertainty interacts with institutional quality to influence the overall attractiveness of countries for foreign investment. To capture these channels and findings, in this paper, we rely on the theory of investment under uncertainty (see, e.g., [32-37]). More specifically, we adapt Dixit's theory [33] to model the institutional-quality-adjusted FDI costs. With a simple example, he shows that the optimal investment trigger under any uncertainty is obviously to the right of the traditional Marshallian investment trigger due to irreversibility of investment.

Given this basic setup, we investigate, in detail, the impacts of institutional quality in the emerging economies. As will be shown later, an improvement of institutional quality in the emerging economies reduces the institutional-quality-adjusted FDI costs, which creates more favorable business environment for multinational firms using high technology. The increase in FDI, in turn, induces pervasive technology-upgrading effects at both individual worker and firm levels, which generates aggregate productivity gains in the advanced economies. Consequently, more varieties produced 
using higher technologies may also increase the aggregate welfare in both emerging and advanced economies. To my best knowledge, this paper is the first study that systematically examines the links between institutional quality in the emerging economies and the aggregate productivity in the advanced economies with a unified theoretical general equilibrium framework.

The rest of the paper is organized as follows. In Section 2, we present the basic setup of the model. In Section 3, we study the effects of institutional quality. Section 4 supplements our theoretical discussions by exploring numerically a parameterized version of the model roughly calibrated on US data. Section 5 concludes with some concluding remarks.

\section{The Model}

\subsection{Preferences}

The world is composed of two regions, emerging and advanced economies. Though, recently, new types of foreign investment, such as the rise in investment from emerging to advanced economies, increasing investment flows between emerging economies, etc., are also receiving attention, we keep the traditional modeling distinction as in the literature of institutional quality and economic development through inward FDI. Recent empirical evidence also supports that the vertical specialization has been the most important FDI motive between advanced and emerging economies [38].

Consumers in both regions have Dixit-Stiglitz preferences over a continuum of varieties. Household preferences are:

$$
X=\left[\int_{i \in N} x(i)^{\rho} d i\right]^{\frac{1}{\rho}},
$$

with $0<\rho<1$. $N$ represents the mass of available varieties and the index $i$ denotes individual varieties. As usual, consumer's optimization yields the demand schedule for each variety associated with an aggregate price index:

$$
\begin{gathered}
x(i)=\left(\frac{p(i)}{P_{X}}\right)^{-\sigma} X, \\
P_{X}=\left[\int_{i \in N} p(i)^{1-\sigma} d i\right]^{\frac{1}{1-\sigma}},
\end{gathered}
$$

where $\sigma=1 /(1-\rho)$ is the elasticity of substitution between varieties and $p(i)$ is the market price for each variety.

\subsection{Technologies and Production Modes}

There is a continuum of firms, each producing a differentiated variety $i$. The production of any variety $x(i)$ requires combining two inputs, headquarter (or management) services $h(i)$ and intermediate components $m(i)$. These two inputs can also be viewed as white-collar tasks and blue-collar tasks, which are not substitutable in general. We assume a Leontief production technology with units conveniently chosen so that $x(i)=h(i)=m(i)$, i.e., producing each final-good variety requires the same quantities of headquarter services and intermediate components.

Firms are free to enter the market and choose where to produce their intermediate components. There are two different production modes: domestic $(D)$ and multinational $(M)$. Domestic firms produce all inputs only domestically, while multinational firms produce intermediate components in the emerging economies through FDI. Organizing global supply chains and benefiting from the cheap labor costs in the emerging economies requires advanced managerial technologies for headquarter services. There is now ample evidence that multinational firms use more productive technologies than domestic firms. Adopting either production mode requires a production-mode-specific technology: $L$ for low-tech domestic firms and $H$ for high-tech multinational firms, with associated fixed set-up $\operatorname{costs} f_{H}>f_{L}$. 
Producing intermediate components is cheaper in the emerging economies than in the advanced economies, with associated marginal production costs $C_{M}^{*}<C_{M}$, but engaging in FDI incurs additional fixed set-up costs $f_{I}$. Additionally, defining $C_{L}$ and $C_{H}$ as the unit cost of $h(i)$ for domestic firms and multinational firms, respectively, and assuming monopolistic competition to prevail in the market so that firms charge a constant markup over marginal production costs, we have:

$$
p_{L}=\frac{\sigma}{\sigma-1}\left(C_{L}+C_{M}\right) \text { and } p_{H}=\frac{\sigma}{\sigma-1}\left(C_{H}+C_{M}^{*}\right)
$$

with associated total fixed costs $f_{L}$ and $f_{H}+f_{I}$, respectively. Fore convenience, we express the fixed costs in terms of forgone output.

\subsection{Technologies and Labor Market}

Recent literature on assignment and globalization with heterogeneous firms and workers in international trade highlights the globalization-induced aggregate productivity effects. Workers choose tasks or occupations based on their comparative advantage and different tasks or occupations require different specific technologies. Consequently, workers' productivity reflects not only their own skill level but also the technology they are employing. If technology would exhibit any increasing returns to skill, globalization-induced equilibrium skill-technology assignment itself would have considerable implications for both emerging and advanced economies. We assume that workers are differentiated by their individual skill level $z$. The skill distribution in the population is given by $G(z)$ with density $g(z)$ on support $(0, \infty)$.

As described in the previous subsection, in the advanced economies there are three technologies $\{M, L, H\}$ : two managerial technologies $L$ and $H$ for domestic and multinational firms, respectively, and a single technology $M$ for producing domestically the intermediate components. Assuming that managerial technology is higher than repetitive production technology, we order $H>L>M$. Let $\varphi_{j}(z)$ denote the total productivity of a worker with skill level $z$ when using technology $j \in\{M, L, H\}$. We assume:

$$
\frac{\partial \varphi_{M}(z)}{\partial z} \frac{1}{\varphi_{M}(z)}<\frac{\partial \varphi_{L}(z)}{\partial z} \frac{1}{\varphi_{L}(z)}<\frac{\partial \varphi_{H}(z)}{\partial z} \frac{1}{\varphi_{H}(z)}
$$

with $\varphi_{j}(0)=1$ for $j \in\{M, L, H\}$. Note that workers with higher $z$ are relatively more productive when matched with higher technologies. This implies that the least skilled workers have a comparative advantage in repetitive production activities, i.e., in producing the intermediate components, while the most skilled workers have a comparative advantage in high technology; the middling workers have a comparative advantage in headquarter services for domestic firms. Let $z_{1}$ and $z_{2}$ denote the equilibrium skill thresholds with $0<z_{1}<z_{2}<\infty$. Then, workers with $z \in\left(0, z_{1}\right)$ produce $\varphi_{M}(z)$ quantity of intermediate components, while workers with $z \in\left(z_{1}, z_{2}\right)$ and $z \in\left(z_{2}, \infty\right)$ produce $\varphi_{L}(z)$ and $\varphi_{H}(z)$ quantities of headquarter services in domestic and multinational firms, respectively. Workers are paid their marginal product:

$$
\begin{gathered}
C_{M} \varphi_{M}(z), z \in\left(0, z_{1}\right) \\
C_{L} \varphi_{L}(z), z \in\left(z_{1}, z_{2}\right) \\
C_{H} \varphi_{H}(z), z \in\left(z_{2}, \infty\right) .
\end{gathered}
$$

Note that the marginal costs (or technology-specific efficiency wage rates) $C_{j}, j \in\{M, L, H\}$, are endogenous and will be determined in the labor market.

\subsection{Institutionial Quality}

In many aspects, institutional quality and uncertainty are very closely related. Poor institutional quality in the emerging economies increases the overall uncertainty associated with all types of investment, including, in particular, FDI. Firms are very reluctant to invest under any kind of uncertainty. The theory of investment under uncertainty suggests that a great deal of inertia (waiting) 
is optimal when dynamic decisions are being made in an uncertain environment, because of the irreversible nature of investment and gradual arriving of information over time. Differently from the traditional economic theory of investment based on Marshall's analysis, this implies that waiting has a positive value if the investment opportunity does not generally disappear in spite of some delay.

Dixit [33] derives the positive value of waiting with a simple example. Suppose one investment project generating net operating revenue flow $R$ per unit time by incurring a sunk-cost $K$. Due to the uncertain nature of the future revenues, $R$ is assumed to follow geometric Brownian motion and future revenues are discounted at a positive rate $\rho$. When waiting is impossible, the Marshallian analysis suggests that the value to be received from investing immediately is $R / \rho-K$. However, when waiting is possible, the project has a positive value even before the real investment. According to Dixit [33], such a positive value of waiting is $B R^{\beta}$, where $B$ is a multiplicative constant and the power $\beta$ depends on the discount rate $\rho$ and the volatility of the revenue $v$ :

$$
\beta=\frac{1}{2}\left[1+\sqrt{1+\frac{8 \rho}{v^{2}}}\right]>1 .
$$

Given this positive value of waiting, firms invest in a project when its expected present value $R / \rho$ covers not only the actual cost of investment $K$ but also the opportunity cost (value of waiting) $B R^{\beta}$. From the convex form of the value of waiting, Figure 1 shows that firms maximize their value when the curve tangentially meets the straight line of $R / \rho-K$.

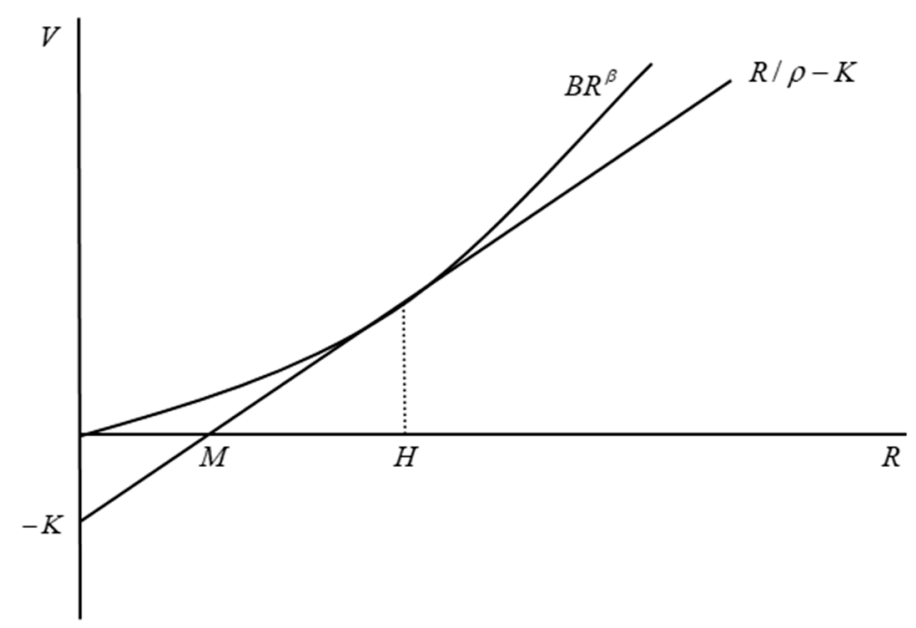

Figure 1. Optimal investment policy. Source: Dixit [33].

Figure 1 suggests that the optimal investment trigger is $H$, which is obviously to right of the traditional Marshallian investment trigger $M$. This new investment trigger under uncertainty is $\beta /(\beta-1)$ times the Marshallian investment trigger: $H=\frac{\beta}{\beta-1} M$.

We introduce the uncertain nature of FDI sunk costs into the model. Specifically, we assume:

$$
f_{I}=\frac{\beta}{\beta-1} f_{I 0}, \quad \beta=\frac{1}{2}\left[1+\sqrt{1+\frac{8 \rho}{v^{2}}}\right],
$$

where $f_{I}$ is now the institutional-quality-adjusted FDI costs and $v$ represents the institutional quality (uncertainty) level in the emerging economies. Equation (8) exhibits a positive relationship between $v$ and $f_{I}$. Thus, a poor institutional quality (high institutional uncertainty; higher $v$ ) leads to higher FDI costs, while an improved institutional quality in the emerging economies (low institutional uncertainty; lower $v$ ) leads to lower FDI costs. Another way of modeling might be assuming another function for $v$. However, since that would only complicate the exposition with no additional insight gained as long as 
there would be a negative relationship between institutional uncertainties and overall quality levels, we keep our formulation (8).

\subsection{Equilibrium}

From the Leontief technology and our characterization of fixed costs as foregone output, labor market equilibrium requires that:

$$
\begin{gathered}
N_{L}\left(x_{L}+f_{L}\right)=\int_{0}^{z_{1}} \varphi_{M}(z) g(z) d z=\int_{z_{1}}^{z_{2}} \varphi_{L}(z) g(z) d z, \\
N_{H}\left(x_{H}+f_{H}+f_{I}\right)=\int_{z_{2}}^{\infty} \varphi_{H}(z) g(z) d z .
\end{gathered}
$$

Free entry ensures zero profits for both firm types so that markup revenues exactly cover the fixed costs:

$$
\begin{gathered}
\frac{1}{\sigma} p_{L} x_{L}=\left(C_{M}+C_{L}\right) f_{L}, \\
\frac{1}{\sigma} p_{H} x_{H}=\left(C_{M}^{*}+C_{H}\right)\left(f_{H}+f_{I}\right) .
\end{gathered}
$$

Labor incomes in both regions follow from employment:

$$
\begin{gathered}
\widetilde{W}=C_{M} \int_{0}^{z_{1}} \varphi_{M}(z) g(z) d z+C_{L} \int_{z_{1}}^{z_{2}} \varphi_{L}(z) g(z) d z+C_{H} \int_{z_{2}}^{\infty} \varphi_{H}(z) g(z) d z \\
\widetilde{W}^{*}=C_{M}^{*} \int_{z_{2}}^{\infty} \varphi_{H}(z) g(z) d z .
\end{gathered}
$$

We assume that labor costs in the emerging economies are paid by multinational firms in units of the consumption basket so that:

$$
P_{X} X=\widetilde{W}+\widetilde{W}^{*}
$$

Finally, in a perfectly competitive labor market, no-arbitrage conditions for the threshold workers determine the marginal production $\operatorname{costs} C_{M}, C_{L}$ and $C_{H}$ : individual workers with skill levels $z_{1}$ and $z_{2}$ should have no incentives to relocate in equilibrium. Choosing $C_{M}$ as our numeraire, we get:

$$
\begin{gathered}
C_{M}=1, \\
C_{L}=C_{M} \varphi_{M}\left(z_{1}\right) / \varphi_{L}\left(z_{1}\right), \\
C_{H}=C_{L} \varphi_{L}\left(z_{2}\right) / \varphi_{H}\left(z_{2}\right) .
\end{gathered}
$$

The full system of equations and determined variables are presented in the Appendix A.

\section{Effects of Institutional Quality}

Now we explore the full model and investigate the impacts of institutional quality. To understand the basic mechanism how the institutional quality in the emerging economies affects both regions, we need to study the competition between domestic firms and multinational firms. Consider the revenue ratio between domestic and multinational firms. From Equations (2), (4), (11) and (12), we get:

$$
\left(\frac{C_{H}+C_{M}^{*}}{C_{L}+C_{M}}\right)=\left(\frac{f_{H}+f_{I}}{f_{L}}\right)^{-\frac{1}{\sigma}}
$$


We start by investigating how the equilibrium skill thresholds $z_{1}$ and $z_{2}$ are affected by any given shock. Totally differentiating the equilibrium condition (9) gives:

$$
\frac{d z_{1}}{d z_{2}}=\frac{\varphi_{L}\left(z_{2}\right) g\left(z_{2}\right)}{\varphi_{M}\left(z_{1}\right) g\left(z_{1}\right)+\varphi_{L}\left(z_{1}\right) g\left(z_{1}\right)}>0,
$$

an expression that is positive.

Substituting Equation (16) into Equation (17) and from Equations (5) and (18), it is then easy to check that a fall in $f_{I}$ induces leftward shifts of $z_{1}$ and $z_{2}$. Leftward shifts of both skill thresholds imply that now more workers are matched with higher technologies: a worker with skill level $z_{1}-\varepsilon$ who was using $M$ technology is now matched with $L$ technology; a worker with skill level $z_{2}-\varepsilon$ who was using $L$ technology is now matched with $H$ technology.

Leftward shifts of $z_{1}$ and $z_{2}$ also imply that now more firms adopt higher technology. From Equations (4) and (9)-(12), we get:

$$
\begin{gathered}
N_{L}=\frac{1}{\sigma f_{L}} \int_{0}^{z_{1}} \varphi_{M}(z) g(z) d z, \\
N_{H}=\frac{1}{\sigma\left(f_{H}+f_{I}\right)} \int_{z_{2}}^{\infty} \varphi_{H}(z) g(z) d z,
\end{gathered}
$$

showing that $\frac{d N_{L}}{d z_{1}}>0$ and $\frac{d N_{H}}{d z_{2}}<0$. The induced effects on the number of firms-a decrease in domestic firms and an increase in multinational firms-obviously imply a rise in FDI.

Note that we are conducting comparative statics in a general equilibrium setting, that is, comparing two different equilibrium states in the long run following a change in some underlying exogenous parameter. Intuitively, a fall in FDI costs favors multinational activities so that more firms turn to multinationals and engage in FDI. This increases labor demand by high-tech multinationals inducing a leftward shift of $z_{2}$; at a given $z_{1}$ and technologies, there is now an oversupply of intermediate components while headquarter (management) services are insufficient in low-tech domestic firms; at least in the long run, there would be new supply-demand equilibrium of workers within domestic firms inducing also a leftward shift of $z_{1}$. These adjustments may of course not be ensured in the short or medium term; the less flexible the labor market, the higher adjustment and disequilibrium costs should be paid.

Returning to our institutional quality formulation, we can now investigate the effects of institutional quality. Consider an improvement of institutional quality in the emerging economies, i.e., a fall in $v$. From Equation (8), a fall in $v$ decreases the institutional-quality-adjusted FDI costs $f_{I}$. As shown above, a fall in $f_{I}$ induces leftward shifts of equilibrium skill thresholds $z_{1}$ and $z_{2}$, which generates technology-upgrading mechanisms on both individual worker and firm levels. Now more firms adopt high technology and turn to multinationals, which increases FDI.

Moreover, an improvement of institutional quality in the emerging economies generates aggregate productivity gains due to the highlighted technology-upgrading mechanisms. Figure 2 shows such productivity effects. The shaded areas in Figure 2 illustrate the economy-wide increased efficiency units of labor. Workers with skill level $z \in\left(z_{1}^{\prime}, z_{1}\right)$-initially producing intermediate components using $M$ technology-are now associated with higher $L$ technology and perform headquarter activities within domestic firms. Similarly, workers with skill level $z \in\left(z_{2}^{\prime}, z_{2}\right)$-initially associated with $L$ technology within low-tech domestic firms-are now matched with the highest $H$ technology within high-tech multinational firms.

Finally, the aggregate productivity gains accompanied by the beneficial compositional effects in the goods market due to the technology upgrading of firms may imply a higher level of welfare. In the next section, we address this question by exploring numerically a parameterized version of the model. 


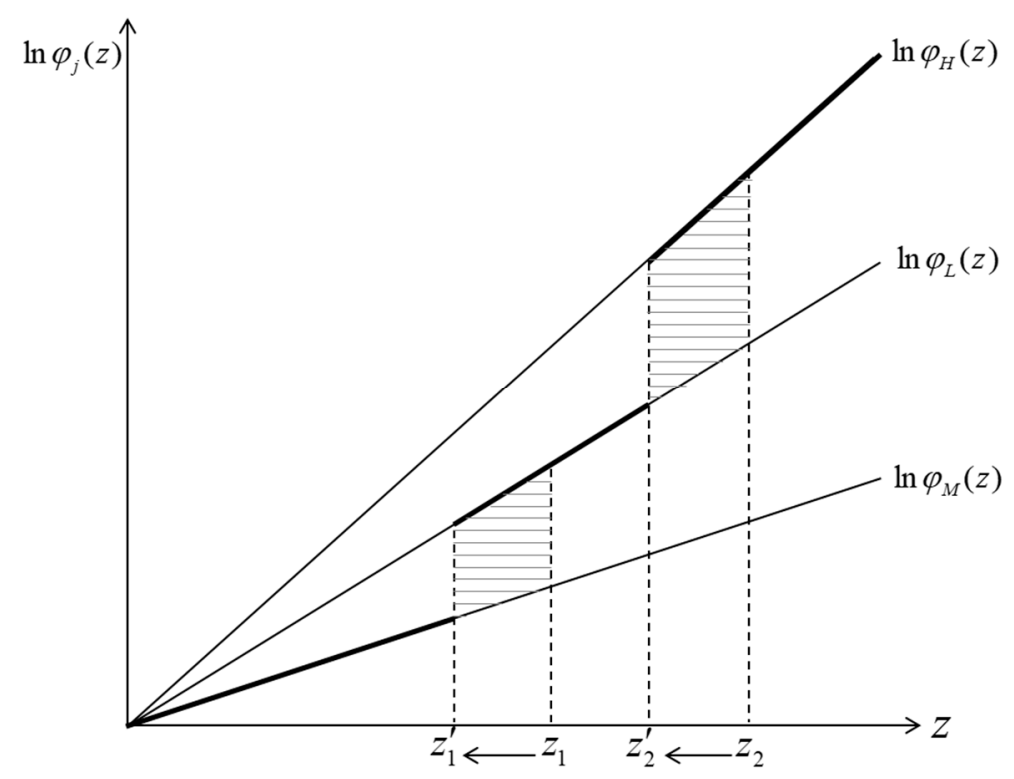

Figure 2. Real productivity gains due to the technology-upgrading mechanism.

\section{Numerical Simulations}

In contrast with previous studies in the literature of institutional quality mostly assuming one representative firm, this paper provides a new theoretical model incorporating heterogeneous firms using different technologies as well as heterogeneous workers in their inherent skills. Moreover, the full general-equilibrium framework makes it hardly possible to derive unambiguous comparative-static results for parameter changes. In particular, in this setup, any parameter changes simultaneously affect all the prices and wages as well as the number of firms so that the implications for welfare and sustainable development cannot be derived analytically. The numerical analyses presented in this section supplement the theory developed under reasonable values of parameters.

\subsection{Calibration}

In this section, we supplement our theoretical discussions with a parameterized version of the model. To get a feeling of the quantitative effects involved, we first set the stage by characterizing the initial equilibrium roughly calibrated to US data. We assume a uniform skill distribution on support $[0,1]$, and log-linear technologies: $\ln \varphi_{j}(z)=a_{j} z, j \in\{M, L, H\}$. International Labour Organization (ILO) provides unit labor costs (relative to the US) for a number of emerging economies, from which we choose $C_{M}^{*}=0.82$. We set $\rho=0.05$ for the discount rate and $\sigma=3$ for the elasticity of substitution between varieties. Following Markusen [39], we choose $f_{L}=1.00, f_{H}=1.19$ and $f_{I 0}=0.40$. Finally, following Dixit [33], we choose $v=0.2$ as a base case, which leads to $f_{I}=0.75$.

Given these parameter values and functional forms, we calibrate the technological parameter values $\left(a_{M}, a_{L}\right.$ and $\left.a_{H}\right)$ by characterizing the initial equilibrium as follows.

1. M-workers represent $70 \%$ of the population. US Economic Census reports that the ratio of production workers to total employees in manufacturing is about $70 \%$. Initially, we choose $z_{1}=0.7$.

2. From the same source, we pick the non-production workers' wage share in total value added from labor as $\frac{C_{L} \int_{z_{1}}^{z_{2}} \varphi_{L}(z) g(z) d z+C_{H} \int_{z_{2}}^{1} \varphi_{H}(z) g(z) d z}{\widetilde{W}}=0.42$.

3. US Economic Census also reports industry statistics by employment size. We approximate multinationals' total output share as that of establishments with 2500 or more employees: $\frac{\int_{z_{2}}^{1} \varphi_{H}(z) g(z) d z}{\int_{z_{1}}^{z_{2}} \varphi_{L}(z) g(z) d z+\int_{z_{2}}^{1} \varphi_{H}(z) g(z) d z}=0.14$. 
The calibrated technological parameter values are: $a_{M}=0.87, a_{L}=1.50$ and $a_{H}=1.77$.

\subsection{Effects on FDI}

With the above parameterization, we can depict the evolution of endogenous variables for different institutional quality levels in the emerging economies. Given the importance of the elasticity of substitution for the results in this type of monopolistic competition models, in the following, we report the results of using alternative values of $\sigma$. The detailed simulation results for alternative values of $\sigma$ are reported in Tables A1-A4 in the Appendix B.

Figure 3 first shows the impact of institutional quality on FDI. Note that, in the following figures, the horizontal axis represents different values of $v$, i.e., moving from left (higher $v$ ) to right (lower $v$ ) represents an improvement of institutional quality in the emerging economies. We measure the FDI levels as the total efficiency units of labor employed in the emerging economies by multinational firms, which are equal to $\int_{z_{2}}^{1} \varphi_{H}(z) g(z) d z$. The FDI levels are normalized to one at the base case $(v=0.2)$. As discussed in Section 3, Figure 4 shows an overall increase in FDI following a fall in $v$, and this for all other reasonable values of $\sigma$.

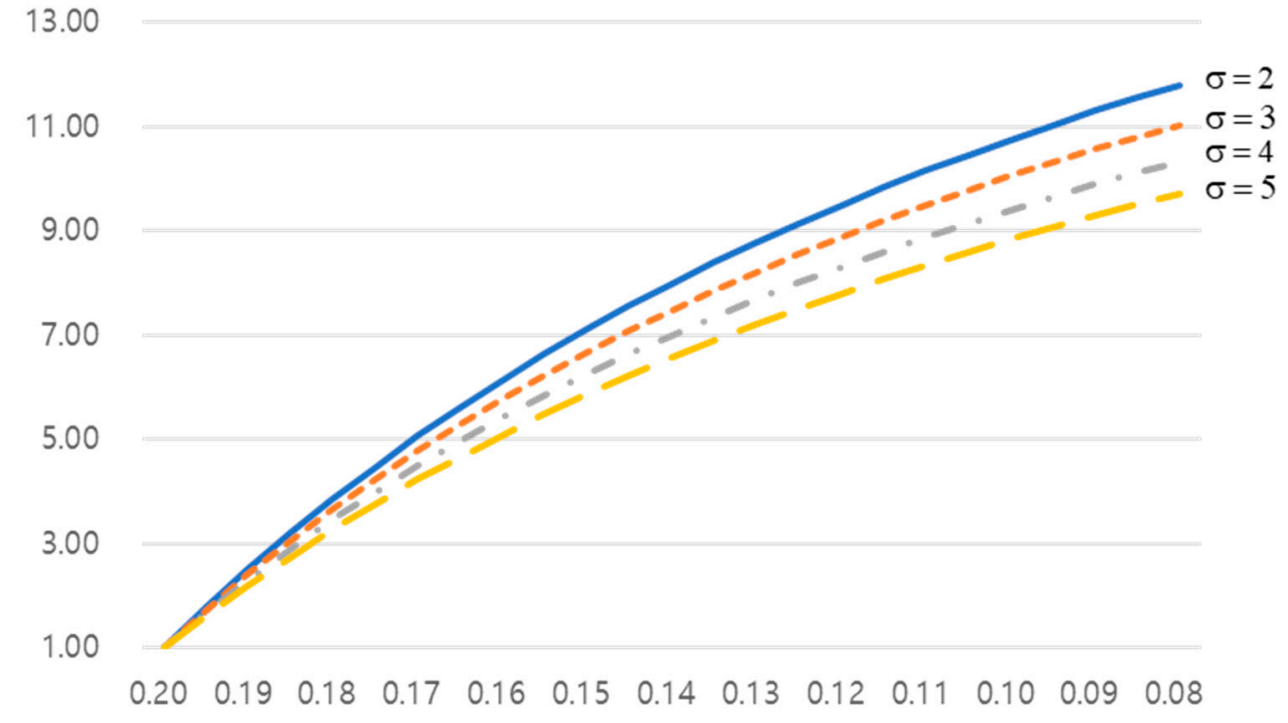

Figure 3. Impact of institutional quality on foreign direct investment (FDI).

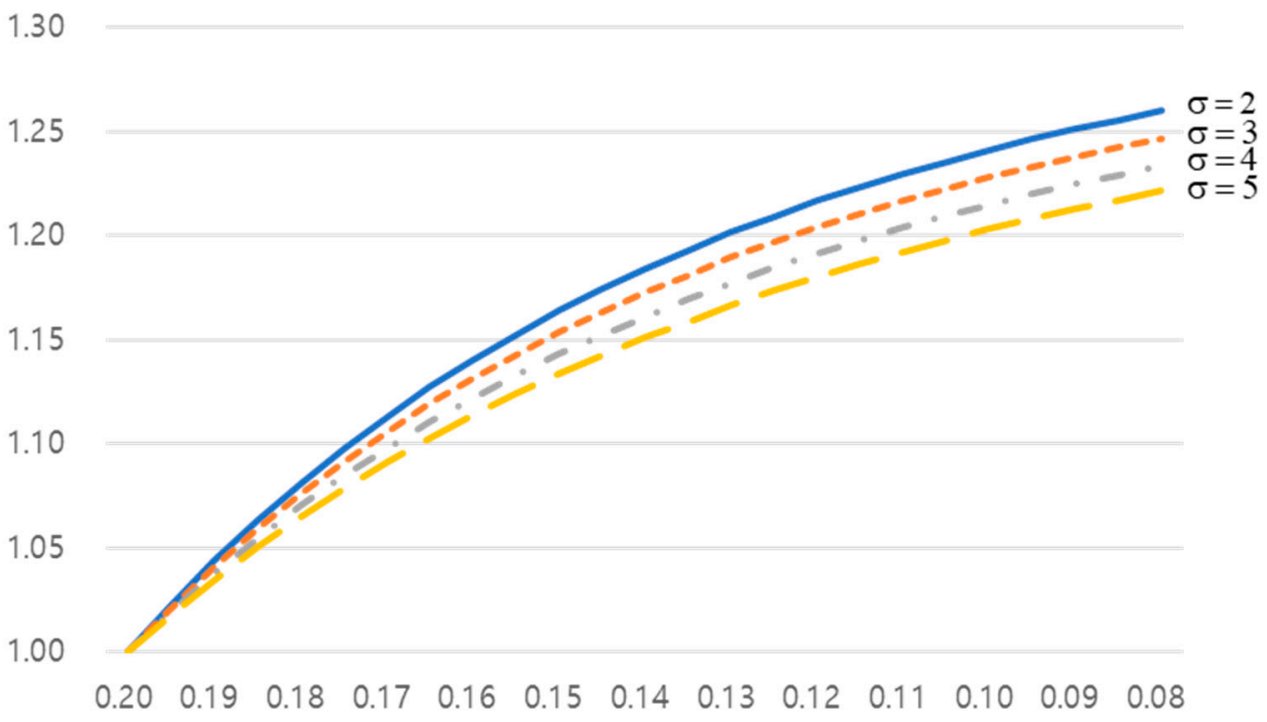

Figure 4. Impact of institutional quality on productivity. 


\subsection{Effects on Productivity}

Figure 4 shows the impact of institutional quality on productivity. We measure the aggregate productivity level in the advanced economies as the total efficiency units of labor, i.e., $\int_{0}^{z_{1}} \varphi_{M}(z) g(z) d z+$ $\int_{z_{1}}^{z_{2}} \varphi_{L}(z) g(z) d z+\int_{z_{2}}^{1} \varphi_{H}(z) g(z) d z$, which is normalized to one at the base case $(v=0.2)$. As discussed with Figure 2 in Section 3, an improvement of institutional quality in the emerging economies generates technology-upgrading mechanisms in the advanced economies. A fall in $v$ induces more firms to adopt high technology and turn to multinationals, which results simultaneously in skill-technology reassignments in the labor market. The economy-wide technology-augmented labor productivity increases in the advanced economies. Figure 4 shows that such effects would be valid for all reasonable values of $\sigma$.

Many empirical works in the literature of FDI spillovers investigated the effects of inward FDI on productivity. In particular, using threshold regression models, they highlighted the presence of nonlinear threshold effects and the role of absorptive capacity for technology spillovers (see, e.g., [40,41]). While previous studies have focused on the host country productivity effects through inward FDI, this paper's theoretical analysis provides new insights for the relationship between host country's institutional quality and home country's productivity effects, which are empirically testable. Applying a threshold regression method might also find some nonlinear threshold effects in the home country according to the institutional quality level in the host country. If some nonlinear threshold effects would exist, that implies that the policy coordination and cooperation between advanced and emerging economies could be very important for sustainable development for both regions.

\subsection{Effects on Welfare}

Finally, Figures 5 and 6 show the impact of institutional quality on welfare for both economies. We measure welfare as the aggregate real income of both economies, $\frac{\widetilde{W}}{P_{X}}$ and $\frac{\widetilde{W}^{*}}{P_{X}}$, respectively. Figures 5 and 6 display significantly high welfare gains for both economies. Though, not surprisingly, the emerging economies are affected relatively more positively, the advanced economies are also associated with high welfare gains, which again implies that institutional quality policies in the emerging economies matter not only for the countries directly concerned, but also for the outside advanced countries. Recently, by adapting a similar heterogeneous worker and firm framework to a model of international trade between two symmetric countries, Jung [29] also highlights a significantly higher welfare improving effect of trade liberalization compared to traditional trade models.

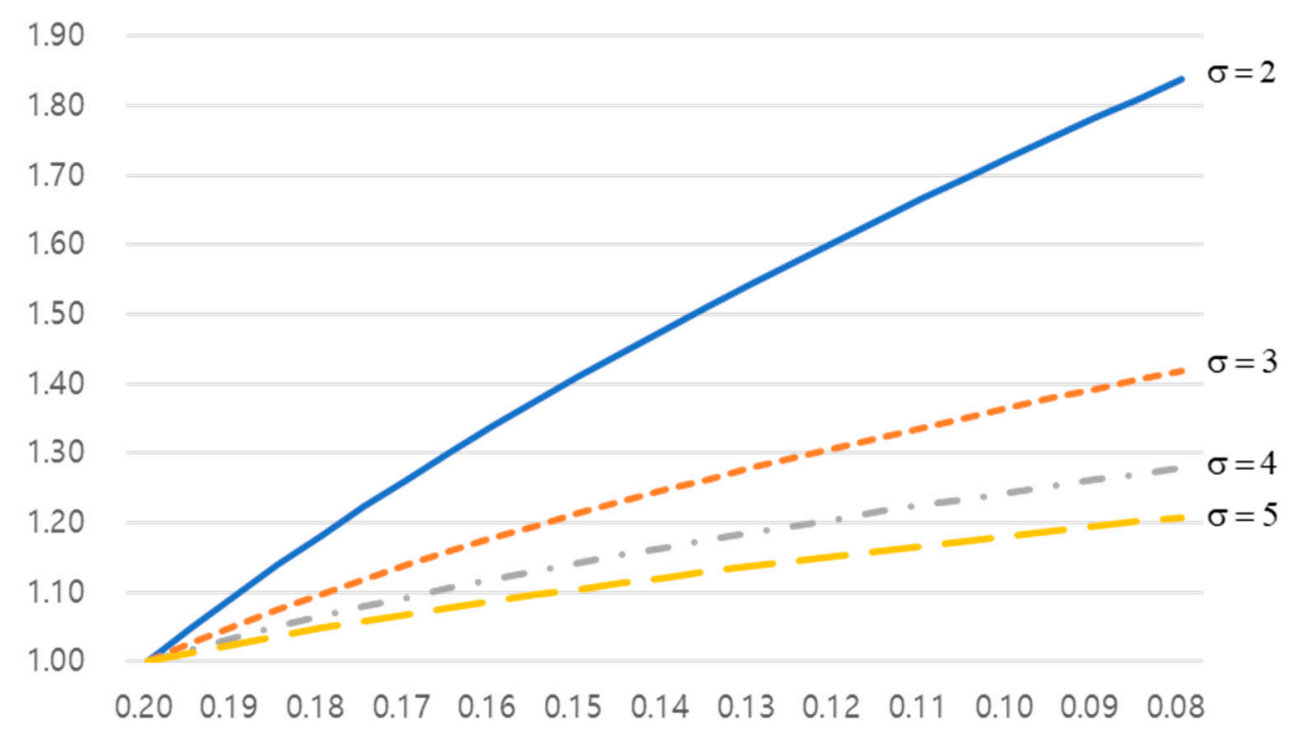

Figure 5. Impact of institutional quality on welfare (advanced economies). 


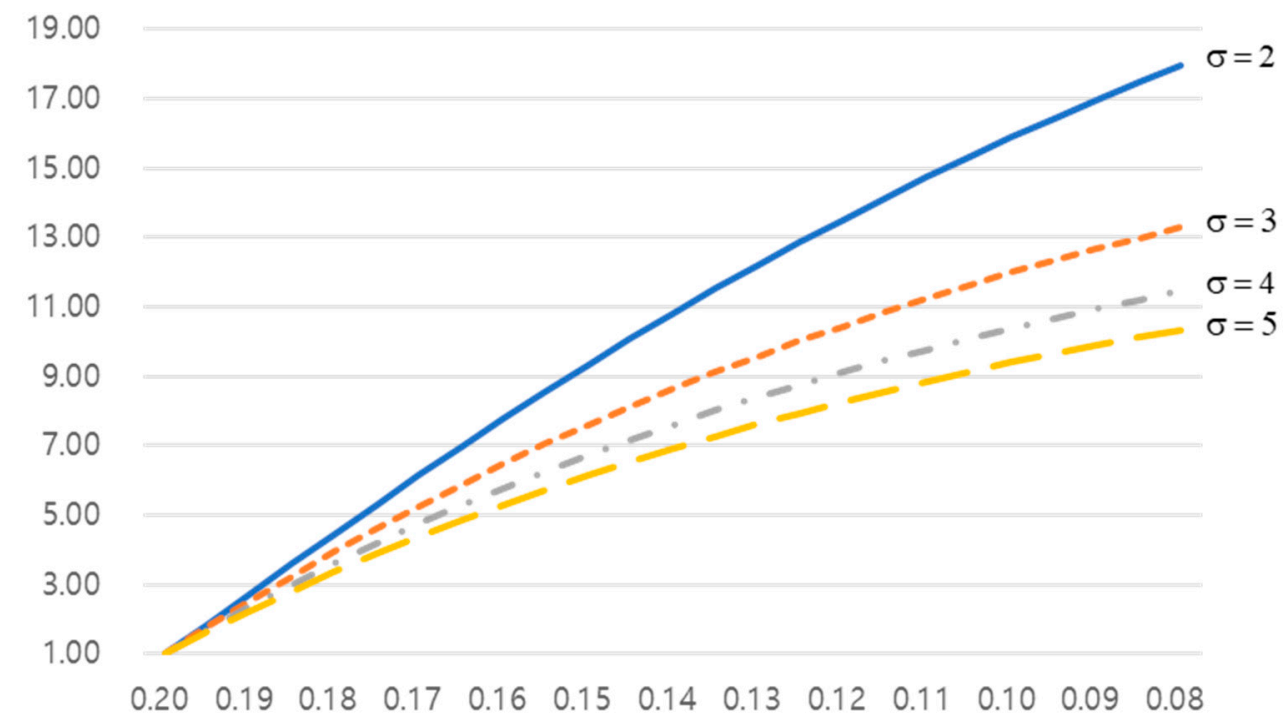

Figure 6. Impact of institutional quality on welfare (emerging economies).

Since the publication of the Brundtland Report in 1987, the concept of sustainable development has been developing over the past decades, with its focus shifted more toward economic and social development. In this regard, sustainable development is also defined as sustainable human welfare over time since an economy can be seen as developing in a sustainable way as long as the average individual is not becoming worse off [42]. In a similar vein, the measure of wealth has also been expanding to include a broadly defined capital that affects the welfare of individuals: a sustainable welfare of individuals therefore indicates that the economy is developing in a sustainable way with a sustainable capital accumulation [43]. In this respect, Figures 5 and 6 also highlight the relationship between the institutional quality and the sustainable development in both regions.

It is also noteworthy that, here, a relatively small decrease in $v$ leads to significantly high welfare gains in the advanced economies. Given the main focus of the paper-i.e., highlighting the institutional quality-FDI-productivity link within a unified theoretical general equilibrium framework - the developed theoretical model is highly stylized in several aspects. For example, in our model, multinational firms use only foreign intermediate components produced in the emerging economies. Relaxing such an assumption as well as adding some more realism-e.g., by introducing any adjustment costs-could of course mitigate the results. However, the main conclusions of the paper would not change as long as an improvement of institutional quality in the emerging economies creates a more favorable environment for multinational activities.

\section{Conclusions}

Many economists and businessmen often argue that the nature of globalization has been changing dramatically in that today it is occurring at a much finer level of disaggregation between advanced and emerging economies. In particular, recent institutional progress in many emerging countries coupled with the extensive development of transportation and communication technologies during the last decades provided firms with strong new incentives to engage in FDI. Consequently, a huge amount of research in the literature on economic development has been devoted to identifying the determinants of FDI and/or to study the possible effects of FDI on economic development.

Though many important links between institutional quality, FDI, and economic development have been uncovered, most studies in the literature have analyzed advanced and emerging economies separately, thereby with limited insights into the full relationship and potential implications. In this paper, we developed a model of FDI incorporating heterogeneous firms and workers employing different technologies as well as institutional-quality-adjusted FDI costs and analyzed the institutional quality-FDI-productivity link within a unified theoretical general equilibrium framework. 
We have shown that institutional progress in the emerging economies may generate positive effects not only for the countries directly concerned, but also for the outside advanced countries. An improvement of institutional quality in the emerging economies reduces the institutionalquality-adjusted FDI costs and creates a more favorable business environment for multinational activities requiring high technology adoption, which, in turn, induces pervasive technology-upgrading effects in the advanced (source) countries. We have also shown that the induced positive productivity effects of institutional progress may generate significantly high welfare gains for both emerging and advanced economies.

Given the close interdependence between emerging and advanced economies in today's globalization process, many interesting research questions may arise. Needless to say, some greater elaboration of our simplified setup-e.g., modeling another heterogeneous firm in the emerging economies and incorporating innovation competition between the two regions, introducing labor market imperfections in both regions, endogenizing institutional quality and considering government policies to improve it, endogenizing technologies and considering the role technology gaps, etc.-might be an interesting direction for future research. Based on the model's new implications, empirically investigating the link between host country institutional quality and home country aggregate productivity using, for example, a threshold regression model, would also be a promising direction for future research.

In terms of economic policy implications, the main message from this paper should be that any policy change in one country could have considerable repercussions for the sustainability of all surrounding countries. I believe that this paper opens up new avenues for various promising extensions and for future research.

Funding: The present research was supported by the research fund of Dankook University in 2020.

Conflicts of Interest: The author declares no conflict of interest.

\section{Appendix A}

System of Equations

$<$ Households $>$

$$
\begin{gathered}
\widetilde{W}=C_{M} \text { OutputM }+C_{L} \text { OutputL }+C_{H} \text { Output } H \\
P_{X} X=\widetilde{W} \\
x_{L}^{d}=\left(\frac{p_{L}}{P_{X}}\right)^{-\sigma} X \\
x_{H}^{d}=\left(\frac{p_{H}}{P_{X}}\right)^{-\sigma} X \\
P_{X}=\left[N_{L} p_{L}^{1-\sigma}+N_{H} p_{H}^{1-\sigma}\right]^{\frac{1}{1-\sigma}}
\end{gathered}
$$

$<$ Households* $>$

$$
\begin{gathered}
\widetilde{W}^{*}=C_{M}^{*} \text { OutputM } \\
P_{X} X^{*}=\widetilde{W}^{*} \\
x_{L}^{d *}=\left(\frac{p_{L}}{P_{X}}\right)^{-\sigma} X^{*} \\
x_{H}^{d *}=\left(\frac{p_{H}}{P_{X}}\right)^{-\sigma} X^{*}
\end{gathered}
$$


$<$ Firms $>$

$$
\begin{gathered}
p_{L}=\frac{\sigma}{\sigma-1}\left(C_{L}+C_{M}\right) \\
p_{H}=\frac{\sigma}{\sigma-1}\left(C_{H}+C_{M}^{*}\right) \\
\text { OutputM }=\int_{0}^{z_{1}} \varphi_{M}(z) g(z) d z \\
\text { OutputL }=\int_{z_{1}}^{z_{2}} \varphi_{L}(z) g(z) d z \\
\text { OutputH }=\int_{z_{2}}^{\infty} \varphi_{H}(z) g(z) d z \\
x_{L}=x_{L}^{d}+x_{L}^{d *} \\
x_{H}=x_{H}^{d}+x_{H}^{d *}
\end{gathered}
$$

$<$ Equilibrium $>$

$$
\begin{gathered}
C_{L}=C_{M} \frac{\varphi_{M}\left(z_{1}\right)}{\varphi_{L}\left(z_{1}\right)} \\
C_{H}=C_{L} \frac{\varphi_{L}\left(z_{2}\right)}{\varphi_{H}\left(z_{2}\right)} \\
\frac{1}{\sigma} p_{L} x_{L}=\left(C_{M}+C_{L}\right) f_{L} \\
\frac{1}{\sigma} p_{H} x_{H}=\left(C_{M}^{*}+C_{H}\right)\left(f_{H}+f_{I}\right) \\
f_{I}=\frac{\beta}{\beta-1} f_{I 0} \\
\beta=\frac{1}{2}\left[1+\sqrt{1+\frac{8 \rho}{v^{2}}}\right] \\
\text { OutputM }=\text { OutputL } \\
\text { OutputM } M^{*}=\text { OutputH } \\
N_{L}\left(x_{L}+f_{L}\right)=\text { OutputL } \\
N_{H}\left(x_{H}+f_{H}+f_{I}\right)=\text { OutputH }
\end{gathered}
$$

\section{Appendix B}

Simulated Effects of Institutonal Quality for Alternative Values of $\sigma$

In the following tables, the Fdi, Prod, Welf and Welf* variables represent the measured levels of total FDI, aggregate productivity, aggregate real incomes for advanced and emerging economies, repectively, which are normalized to one at the base case of $v=0.2$. 
Table A1. The effects of falls in $v$ when $\sigma=2$.

\begin{tabular}{|c|c|c|c|c|c|c|c|c|c|c|c|c|c|}
\hline$v$ & $N_{L}$ & $N_{H}$ & $\tilde{W}$ & $P_{X}$ & $z_{1}$ & $z_{2}$ & $C_{L}$ & $C_{H}$ & $\tilde{W}^{*}$ & Fdi & Prod & Welf & Welf \\
\hline 0.200 & 0.483 & 0.041 & 1.664 & 6.097 & 0.700 & 0.973 & 0.643 & 0.499 & 0.107 & 1.000 & 1.000 & 1.000 & 1.000 \\
\hline 0.195 & 0.464 & 0.073 & 1.674 & 5.849 & 0.679 & 0.950 & 0.651 & 0.508 & 0.191 & 1.782 & 1.023 & 1.049 & 1.857 \\
\hline 0.190 & 0.446 & 0.103 & 1.685 & 5.637 & 0.660 & 0.928 & 0.660 & 0.518 & 0.270 & 2.518 & & 1.095 & 2.722 \\
\hline 0.185 & 0.429 & 0.133 & 1.696 & 5.454 & 0.640 & 0.906 & 0.668 & 0.527 & 0.344 & 3.211 & 1.063 & 1.139 & 3.588 \\
\hline 0.180 & 0.412 & 0.161 & 1.708 & 5.293 & 0.621 & 0.885 & 0.676 & 0.536 & 0.414 & 3.865 & 1.081 & 1.182 & 4.450 \\
\hline 0.175 & 0.397 & 0.187 & 1.720 & 5.152 & 0.603 & 0.865 & 0.684 & 0.545 & 0.480 & 4.482 & 1.098 & 1.223 & 5.303 \\
\hline 0.170 & 0.382 & 0.213 & 1.733 & 5.027 & 0.585 & 0.844 & 0.691 & 0.554 & 0.543 & 5.066 & 1.113 & 1.263 & 6.143 \\
\hline 0.165 & 0.368 & 0.237 & 1.746 & 4.916 & 0.568 & 0.824 & 0.699 & 0.563 & 0.602 & 5.619 & 1.127 & 1.302 & 6.967 \\
\hline 0.160 & 0.354 & 0.261 & 1.760 & 4.816 & 0.551 & 0.805 & 0.706 & 0.572 & 0.658 & 6.143 & 1.141 & 1.339 & 7.775 \\
\hline 0.155 & 0.341 & 0.284 & 1.774 & 4.726 & 0.535 & 0.786 & 0.714 & 0.581 & 0.712 & 6.640 & 1.153 & 1.375 & 8.563 \\
\hline 0.150 & 0.328 & 0.305 & 1.788 & 4.645 & 0.519 & 0.767 & 0.721 & 0.590 & 0.762 & 7.111 & 1.164 & 1.411 & 9.332 \\
\hline 0.145 & 0.316 & 0.326 & 1.803 & 4.571 & 0.503 & 0.748 & 0.728 & 0.599 & 0.810 & 7.560 & 1.175 & 1.445 & 10.080 \\
\hline 0.140 & 0.304 & 0.347 & 1.818 & 4.504 & 0.488 & 0.730 & 0.735 & 0.607 & 0.856 & 7.986 & 1.184 & 1.479 & 10.808 \\
\hline 0.135 & 0.293 & 0.366 & 1.833 & 4.442 & 0.473 & 0.712 & 0.742 & 0.616 & 0.899 & 8.392 & 1.193 & 1.512 & 11.515 \\
\hline 0.130 & 0.282 & 0.385 & 1.848 & 4.386 & 0.459 & 0.695 & 0.749 & 0.624 & 0.941 & 8.778 & 1.202 & 1.544 & 12.201 \\
\hline 0.125 & 0.272 & 0.403 & 1.863 & 4.334 & 0.445 & 0.678 & 0.755 & & 0.980 & 9.1 & & 1.576 & 12.865 \\
\hline 0.120 & 0.262 & 0.421 & 1.879 & 4.285 & 0.431 & 0.661 & 0.762 & 0.641 & 1.018 & 9.498 & 1.217 & 1.607 & 13.510 \\
\hline 0.115 & 0.252 & 0.438 & 1.895 & 4.241 & 0.418 & 0.644 & 0.768 & 0.649 & 1.054 & 9.835 & 1.224 & 1.637 & 14.135 \\
\hline 0.110 & 0.243 & 0.455 & 1.911 & 4.200 & 0.405 & 0.628 & 0.775 & 0.657 & 1.088 & 10.155 & 1.230 & 1.667 & 14.739 \\
\hline 0.105 & 0.234 & 0.471 & 1.927 & 4.161 & 0.392 & 0.611 & 0.781 & 0.665 & 1.121 & 10.461 & 1.236 & 1.697 & 15.324 \\
\hline 0.100 & 0.225 & 0.486 & 1.943 & 4.126 & 0.380 & 0.596 & 0.787 & 0.673 & 1.153 & 10.755 & 1.241 & 1.726 & 15.889 \\
\hline 0.095 & 0.217 & 0.501 & 1.959 & 4.092 & 0.368 & 0.580 & 0.793 & 0.681 & 1.183 & 11.035 & 1.247 & 1.754 & 16.438 \\
\hline 0.090 & 0.209 & 0.516 & 1.975 & 4.061 & 0.356 & 0.565 & 0.799 & 0.689 & 1.212 & 11.304 & 1.251 & 1.783 & 16.967 \\
\hline 0.085 & 0.201 & 0.530 & 1.992 & 4.031 & 0.345 & 0.549 & 0.805 & 0.697 & 1.239 & 11.561 & 1.256 & 1.810 & 17.480 \\
\hline 0.080 & 0.194 & 0.544 & 2.008 & 4.004 & 0.334 & 0.535 & 0.810 & 0.705 & 1.266 & 11.808 & 1.260 & 1.838 & 17.977 \\
\hline
\end{tabular}

Table A2. The effects of falls in $v$ when $\sigma=3$.

\begin{tabular}{|c|c|c|c|c|c|c|c|c|c|c|c|c|c|}
\hline$v$ & $N_{L}$ & $N_{H}$ & $\tilde{W}$ & $P_{X}$ & $z_{1}$ & $z_{2}$ & $C_{L}$ & $C_{H}$ & $\tilde{W}^{*}$ & Fdi & Prod & Welf & Welf \\
\hline 0.200 & 0.322 & 0.027 & 1.664 & 4.087 & 0.700 & 0.973 & 0.643 & 0.499 & 0.129 & 1.000 & 1.000 & 1.000 & 1.000 \\
\hline 0.195 & 0.310 & 0.047 & 1.673 & 4.002 & 0.681 & 0.951 & 0.651 & 0.508 & 0.223 & 1.731 & 1.021 & 1.027 & 1.768 \\
\hline 0.190 & 0.299 & 0.066 & 1.683 & 3.929 & 0.662 & 0.931 & 0.659 & 0.516 & 0.311 & 2.418 & 1.041 & 1.052 & 2.514 \\
\hline 0.185 & 0.288 & 0.084 & 1.693 & 3.866 & 0.644 & 0.911 & 0.666 & 0.525 & 0.395 & 3.064 & 1.059 & 1.076 & 3.237 \\
\hline 0.180 & 0.278 & 0.102 & 1.704 & 3.812 & 0.627 & 0.892 & 0.673 & 0.533 & 0.473 & 3.672 & 1.076 & 1.098 & 3.935 \\
\hline 0.175 & 0.269 & 0.118 & 1.715 & 3.764 & 0.610 & 0.873 & 0.681 & 0.542 & 0.547 & 4.244 & 1.092 & 1.119 & 4.608 \\
\hline 0.170 & 0.259 & 0.134 & 1.727 & 3.721 & 0.594 & 0.854 & 0.688 & 0.550 & 0.616 & 4.786 & 1.106 & 1.140 & 5.255 \\
\hline 0.165 & 0.251 & 0.149 & 1.738 & 3.683 & 0.578 & 0.836 & 0.694 & 0.558 & 0.682 & 5.299 & 1.119 & 1.159 & 5.877 \\
\hline 0.160 & 0.242 & 0.164 & 1.750 & 3.650 & 0.563 & 0.818 & 0.701 & 0.566 & 0.745 & 5.784 & 1.132 & 1.178 & 6.474 \\
\hline 0.155 & 0.234 & 0.178 & 1.763 & 3.619 & 0.548 & 0.801 & 0.708 & 0.574 & 0.804 & 6.243 & 1.143 & 1.196 & 7.047 \\
\hline 0.150 & 0.226 & 0.191 & 1.775 & 3.592 & 0.533 & 0.784 & 0.714 & 0.582 & 0.860 & 6.680 & 1.154 & 1.214 & 7.596 \\
\hline 0.145 & 0.219 & 0.204 & 1.788 & 3.568 & 0.519 & 0.768 & 0.721 & 0.590 & 0.914 & 7.095 & 1.164 & 1.231 & 8.124 \\
\hline 0.140 & 0.212 & 0.217 & 1.800 & 3.546 & 0.506 & 0.751 & 0.727 & 0.597 & 0.964 & 7.489 & 1.173 & 1.247 & 8.629 \\
\hline 0.135 & 0.205 & 0.229 & 1.813 & 3.526 & 0.492 & 0.735 & 0.733 & 0.605 & 1.013 & 7.865 & 1.181 & 1.263 & 9.114 \\
\hline 0.130 & 0.199 & 0.240 & 1.826 & 3.508 & 0.480 & 0.720 & 0.739 & 0.612 & 1.059 & 8.223 & 1.190 & 1.279 & 9.578 \\
\hline 0.125 & 0.192 & 0.252 & 1.839 & 3.491 & 0.467 & 0.705 & 0.745 & 0.620 & 1.103 & 8.565 & 1.197 & 1.294 & 10.024 \\
\hline 0.120 & 0.186 & 0.263 & 1.853 & 3.476 & 0.455 & 0.690 & 0.751 & 0.627 & 1.145 & 8.891 & 1.204 & 1.309 & 10.451 \\
\hline 0.115 & 0.180 & 0.273 & 1.866 & 3.462 & 0.443 & 0.675 & 0.756 & 0.634 & 1.185 & 9.203 & 1.211 & 1.324 & 10.860 \\
\hline 0.110 & 0.175 & 0.284 & 1.879 & 3.449 & 0.431 & 0.661 & 0.762 & 0.641 & 1.223 & 9.501 & 1.217 & 1.338 & 11.253 \\
\hline 0.105 & 0.169 & 0.294 & 1.893 & 3.438 & 0.420 & 0.646 & 0.767 & 0.648 & 1.260 & 9.786 & 1.223 & 1.352 & 11.630 \\
\hline 0.100 & 0.164 & 0.303 & 1.906 & 3.427 & 0.409 & 0.633 & 0.773 & 0.655 & 1.295 & 10.059 & 1.228 & 1.366 & 11.992 \\
\hline 0.095 & 0.159 & 0.313 & 1.919 & 3.417 & 0.398 & 0.619 & 0.778 & 0.662 & 1.329 & 10.321 & 1.233 & 1.380 & 12.339 \\
\hline 0.090 & 0.154 & 0.322 & 1.933 & 3.408 & 0.388 & 0.606 & 0.783 & 0.668 & 1.361 & 10.572 & 1.238 & 1.393 & 12.672 \\
\hline 0.085 & 0.149 & 0.331 & 1.946 & 3.400 & 0.378 & 0.592 & 0.788 & 0.675 & 1.392 & 10.812 & 1.242 & 1.406 & 12.993 \\
\hline 0.080 & 0.145 & 0.339 & 1.960 & 3.392 & 0.368 & 0.580 & 0.793 & 0.682 & 1.422 & 11.043 & 1.247 & 1.419 & 13.300 \\
\hline
\end{tabular}


Table A3. The effects of falls in $v$ when $\sigma=4$.

\begin{tabular}{|c|c|c|c|c|c|c|c|c|c|c|c|c|c|}
\hline$v$ & $N_{L}$ & $N_{H}$ & $\tilde{W}$ & $P_{X}$ & $z_{1}$ & $z_{2}$ & $C_{L}$ & $C_{H}$ & $\tilde{W}^{*}$ & Fdi & Prod & Welf & Welf \\
\hline 0.200 & 0.241 & 0.020 & 1.664 & 3.371 & 0.700 & 0.973 & 0.643 & 0.499 & 0.141 & 1.000 & 1.000 & 1.000 & 1.000 \\
\hline 0.195 & 0.233 & 0.034 & 1.672 & 3.328 & 0.682 & 0.953 & 0.650 & 0.507 & 0.235 & 1.674 & 1.020 & 1.018 & 1.695 \\
\hline 0.190 & 0.226 & 0.047 & 1.681 & 3.292 & 0.665 & 0.934 & 0.657 & 0.515 & 0.324 & 2.307 & & 1.035 & 2.363 \\
\hline 0.185 & 0.218 & 0.060 & 1.691 & 3.260 & 0.649 & 0.916 & 0.664 & 0.523 & 0.408 & 2.903 & 1.055 & 1.051 & 3.001 \\
\hline 0.180 & 0.211 & 0.072 & 1.700 & 3.233 & 0.633 & 0.898 & 0.671 & 0.530 & 0.487 & 3.464 & 1.070 & 1.065 & 3.612 \\
\hline 0.175 & 0.205 & 0.083 & 1.710 & 3.209 & 0.618 & 0.881 & 0.677 & 0.538 & 0.561 & 3.994 & 1.085 & 1.080 & 4.195 \\
\hline 0.170 & 0.198 & 0.094 & 1.720 & 3.188 & 0.603 & 0.864 & 0.684 & 0.545 & 0.631 & 4.495 & 1.098 & 1.093 & 4.751 \\
\hline 0.165 & 0.192 & 0.105 & 1.731 & 3.170 & 0.588 & 0.848 & 0.690 & 0.553 & 0.698 & 4.969 & 1.111 & 1.106 & 5.283 \\
\hline 0.160 & 0.186 & 0.115 & 1.741 & 3.153 & 0.574 & 0.832 & 0.696 & 0.560 & 0.761 & 5.418 & 1.122 & 1.119 & 5.791 \\
\hline 0.155 & 0.181 & 0.125 & 1.752 & 3.139 & 0.561 & 0.816 & 0.702 & 0.567 & 0.821 & 5.845 & 1.133 & 1.131 & 6.275 \\
\hline 0.150 & 0.176 & 0.134 & 1.763 & 3.126 & 0.548 & 0.801 & 0.708 & 0.574 & 0.878 & 6.250 & 1.143 & 1.142 & 6.739 \\
\hline 0.145 & 0.170 & 0.143 & 1.774 & 3.115 & 0.535 & 0.786 & 0.714 & 0.581 & 0.932 & 6.636 & 1.153 & 1.154 & 7.181 \\
\hline 0.140 & 0.166 & 0.152 & 1.785 & 3.104 & 0.522 & 0.771 & 0.719 & 0.588 & 0.984 & 7.004 & 1.161 & 1.165 & 7.603 \\
\hline 0.135 & 0.161 & 0.160 & 1.796 & 3.095 & 0.510 & 0.757 & 0.725 & 0.595 & 1.033 & 7.354 & 1.170 & 1.175 & 8.008 \\
\hline 0.130 & 0.156 & 0.169 & 1.807 & 3.087 & 0.499 & 0.743 & 0.730 & 0.601 & 1.080 & 7.689 & 1.177 & 1.186 & 8.394 \\
\hline 0.125 & 0.152 & 0.177 & 1.818 & 3.080 & 0.487 & 0.729 & 0.735 & & 1.125 & 8. & & 1.196 & 8.763 \\
\hline 0.120 & 0.148 & 0.184 & 1.830 & 3.073 & 0.476 & 0.716 & 0.741 & 0.614 & 1.168 & 8.314 & 1.192 & 1.206 & 9.116 \\
\hline 0.115 & 0.144 & 0.192 & 1.841 & 3.067 & 0.465 & 0.703 & 0.746 & 0.620 & 1.209 & 8.606 & 1.198 & 1.216 & 9.455 \\
\hline 0.110 & 0.140 & 0.199 & 1.852 & 3.062 & 0.455 & 0.690 & 0.751 & 0.627 & 1.248 & 8.885 & 1.204 & 1.225 & 9.780 \\
\hline 0.105 & 0.136 & 0.206 & 1.864 & 3.057 & 0.445 & 0.677 & 0.755 & 0.633 & 1.286 & 9.154 & 1.210 & 1.235 & 10.090 \\
\hline 0.100 & 0.132 & 0.213 & 1.875 & 3.053 & 0.435 & 0.665 & 0.760 & 0.639 & 1.322 & 9.411 & 1.215 & 1.244 & 10.388 \\
\hline 0.095 & 0.129 & 0.219 & 1.887 & 3.049 & 0.425 & 0.653 & 0.765 & 0.645 & 1.357 & 9.658 & 1.220 & 1.253 & 10.674 \\
\hline 0.090 & 0.125 & 0.226 & 1.898 & 3.046 & 0.416 & 0.641 & 0.769 & 0.651 & 1.390 & 9.895 & 1.225 & 1.262 & 10.948 \\
\hline 0.085 & 0.122 & 0.232 & 1.909 & 3.043 & 0.406 & 0.629 & 0.774 & 0.656 & 1.422 & 10.122 & 1.229 & 1.271 & 11.211 \\
\hline 0.080 & 0.119 & 0.238 & 1.920 & 3.040 & 0.397 & 0.618 & 0.778 & 0.662 & 1.453 & 10.341 & 1.234 & 1.280 & 11.463 \\
\hline
\end{tabular}

Table A4. The effects of falls in $v$ when $\sigma=5$.

\begin{tabular}{|c|c|c|c|c|c|c|c|c|c|c|c|c|c|}
\hline$v$ & $N_{L}$ & $N_{H}$ & $\tilde{W}$ & $P_{X}$ & $z_{1}$ & $z_{2}$ & $C_{L}$ & $C_{H}$ & $\tilde{W}^{*}$ & $F d i$ & Prod & Welf & Welf \\
\hline 0.200 & 0.193 & 0.016 & 1.664 & 2.997 & 0.700 & 0.973 & 0.643 & 0.499 & 0.148 & 1.000 & 1.000 & 1.000 & 1.000 \\
\hline 0.195 & 0.187 & 0.027 & 1.672 & 2.972 & 0.684 & 0.955 & 0.650 & 0.506 & 0.240 & 1.621 & 1.018 & 1.013 & 1.635 \\
\hline 0.190 & 0.181 & 0.036 & 1.680 & 2.951 & 0.668 & 0.937 & 0.656 & 0.513 & 0.326 & 2.206 & 1.035 & 1.025 & 2.241 \\
\hline 0.185 & 0.176 & 0.046 & 1.688 & 2.932 & 0.653 & 0.921 & 0.662 & 0.521 & 0.408 & 2.756 & 1.051 & 1.037 & 2.818 \\
\hline 0.180 & 0.171 & 0.054 & 1.697 & 2.917 & 0.638 & 0.904 & 0.669 & 0.528 & 0.484 & 3.276 & 1.065 & 1.048 & 3.367 \\
\hline 0.175 & 0.166 & 0.063 & 1.706 & 2.903 & 0.624 & 0.888 & 0.675 & 0.535 & 0.557 & 3.767 & 1.079 & 1.058 & 3.890 \\
\hline 0.170 & 0.161 & 0.071 & 1.715 & 2.891 & 0.611 & 0.873 & 0.680 & 0.542 & 0.626 & 4.232 & 1.091 & 1.068 & 4.388 \\
\hline 0.165 & 0.157 & 0.079 & 1.724 & 2.881 & 0.597 & 0.858 & 0.686 & 0.548 & 0.691 & 4.673 & 1.103 & 1.078 & 4.862 \\
\hline 0.160 & 0.153 & 0.087 & 1.734 & 2.872 & 0.584 & 0.843 & 0.692 & 0.555 & 0.753 & 5.092 & 1.114 & 1.087 & 5.315 \\
\hline 0.155 & 0.148 & 0.094 & 1.743 & 2.864 & 0.572 & 0.829 & 0.697 & 0.561 & 0.812 & 5.489 & 1.124 & 1.096 & 5.746 \\
\hline 0.150 & 0.144 & 0.101 & 1.753 & 2.857 & 0.560 & 0.815 & 0.702 & 0.568 & 0.868 & 5.868 & 1.134 & 1.105 & 6.158 \\
\hline 0.145 & 0.141 & 0.108 & 1.762 & 2.851 & 0.548 & 0.802 & 0.708 & 0.574 & 0.921 & 6.229 & 1.143 & 1.113 & 6.550 \\
\hline 0.140 & 0.137 & 0.114 & 1.772 & 2.846 & 0.537 & 0.788 & 0.713 & 0.580 & 0.972 & 6.574 & 1.151 & 1.122 & 6.926 \\
\hline 0.135 & 0.134 & 0.120 & 1.782 & 2.841 & 0.526 & 0.775 & 0.718 & 0.586 & 1.021 & 6.903 & 1.159 & 1.130 & 7.284 \\
\hline 0.130 & 0.130 & 0.127 & 1.792 & 2.837 & 0.515 & 0.763 & 0.723 & 0.592 & 1.067 & 7.218 & 1.167 & 1.138 & 7.627 \\
\hline 0.125 & 0.127 & 0.133 & 1.801 & 2.833 & 0.505 & 0.750 & 0.727 & 0.598 & 1.112 & 7.518 & 1.174 & 1.145 & 7.955 \\
\hline 0.120 & 0.124 & 0.138 & 1.811 & 2.830 & 0.495 & 0.738 & 0.732 & 0.604 & 1.154 & 7.806 & 1.180 & 1.153 & 8.268 \\
\hline 0.115 & 0.121 & 0.144 & 1.821 & 2.828 & 0.485 & 0.726 & 0.737 & 0.609 & 1.195 & 8.082 & 1.186 & 1.160 & 8.569 \\
\hline 0.110 & 0.118 & 0.149 & 1.831 & 2.825 & 0.475 & 0.714 & 0.741 & 0.615 & 1.234 & 8.347 & 1.192 & 1.167 & 8.856 \\
\hline 0.105 & 0.115 & 0.155 & 1.841 & 2.823 & 0.466 & 0.703 & 0.746 & 0.620 & 1.272 & 8.602 & 1.198 & 1.174 & 9.132 \\
\hline 0.100 & 0.112 & 0.160 & 1.851 & 2.822 & 0.456 & 0.692 & 0.750 & 0.626 & 1.308 & 8.845 & 1.203 & 1.181 & 9.396 \\
\hline 0.095 & 0.110 & 0.165 & 1.861 & 2.820 & 0.448 & 0.681 & 0.754 & 0.631 & 1.342 & 9.080 & 1.208 & 1.188 & 9.650 \\
\hline 0.090 & 0.107 & 0.170 & 1.870 & 2.819 & 0.439 & 0.670 & 0.758 & 0.636 & 1.376 & 9.305 & 1.213 & 1.195 & 9.893 \\
\hline 0.085 & 0.105 & 0.175 & 1.880 & 2.818 & 0.430 & 0.659 & 0.762 & 0.642 & 1.408 & 9.522 & 1.217 & 1.202 & 10.128 \\
\hline 0.080 & 0.102 & 0.179 & 1.890 & 2.818 & 0.422 & 0.649 & 0.766 & 0.647 & 1.439 & 9.731 & 1.222 & 1.208 & 10.353 \\
\hline
\end{tabular}




\section{References}

1. UNCTAD. World Investment Report; United Nations: New York, NY, USA, 2019.

2. Wei, S.J. How Taxing is Corruption on International Investors? Rev. Econ. Stat. 2000, 82, 1-11. [CrossRef]

3. Buchanan, B.G.; Quan, V.L.; Meenakshi, R. Foreign direct investment and institutional quality: Some empirical evidence. Int. Rev. Financ. Anal. 2012, 21, 81-89. [CrossRef]

4. Bénassy-Quéré, A.; Coupet, M.; Mayer, T. Institutional Determinants of Foreign Direct Investment. World Econ. 2007, 30, 764-782. [CrossRef]

5. Aizenman, J.; Spiegel, M. Institutional efficiency and the investment share of foreign direct investment. Rev. Int. Econ. 2006, 14, 683-697. [CrossRef]

6. Knack, S.; Keefer, P. Institutions and economic performance: Cross-country tests using alternative institutional measures. Econ. Polit. Oxf. 1995, 7, 207-228. [CrossRef]

7. Lee, J.Y.; Mansfield, E. Intellectual Property Protection and U.S. Foreign Direct Investment. Rev. Econ. Stat. 1996, 78, 181. [CrossRef]

8. Gani, A. Governance and foreign direct investment links: Evidence from panel data estimations. Appl. Econ. Lett. 2007, 14, 753-756. [CrossRef]

9. Daude, C.; Stein, E. The quality of institutions and foreign direct investment. Econ. Polit. Oxf. 2007, 19, 317-344. [CrossRef]

10. Jensen, N.M. Democratic Governance and Multinational Corporations: Political Regimes and Inflows of Foreign Direct Investment. Int. Organ. 2003, 57, 587-616. [CrossRef]

11. Zhang, K.H. Does foreign direct investment promote economic growth? Evidence from East Asia and Latin America. Contemp. Eon. Policy 2001, 19, 175-185. [CrossRef]

12. Makki, S.S.; Somwaru, A. Impact of FDI and trade on economic growth: Evidence from developing countries. Am. J. Agric. Econ. 2004, 86, 795-801. [CrossRef]

13. Liu, Z. Foreign direct investment and technology spillovers: Theory and evidence. J. Dev. Econ. 2008, 85, 176-193. [CrossRef]

14. Bernard, A.; Jensen, B. Exceptional exporter performance: Cause, effect, or both? J. Int. Econ. 1999, 47, 1-25. [CrossRef]

15. Aw, B.; Chung, S.; Roberts, M. Productivity and Turnover in the Export Market: Micro-level Evidence from the Republic of Korea and Taiwan (China). World Bank Econ. Rev. 2000, 14, 65-90. [CrossRef]

16. Clerides, S.; Lach, S.; Tybout, J. Is Learning by Exporting Important? Micro-Dynamic Evidence from Colombia, Mexico, and Morocco. Q. J. Econ. 1998, 113, 903-947. [CrossRef]

17. Helpman, E.; Melitz, M.J.; Yeaple, S.R. Export Versus FDI with Heterogeneous Firms. Am. Econ. Rev. 2004, 94, 300-316. [CrossRef]

18. Girma, S.; Gorg, H.; Strobl, E. Exports, international investment, and plant performance: Evidence form a non-parametric test. Econ. Lett. 2004, 83, 317-324. [CrossRef]

19. Roy, A.D. Some thoughts on the distribution of earnings. Oxf. Econ. Pap. 1951, 3, 135-146. [CrossRef]

20. Melitz, M.J. The impact of trade on intra-industry reallocations and aggregate industry productivity. Econometrica 2003, 71, 1695-1725. [CrossRef]

21. Grossman, G.M.; Maggi, G. Diversity and Trade. Am. Econ. Rev. 2000, 90, 1255-1275. [CrossRef]

22. Grossman, G.M. The Distribution of Talent and the Pattern and Consequences of International Trade. J. Polit. Econ. 2004, 112, 209-239. [CrossRef]

23. Yeaple, S.R. A simple model of firm heterogeneity, international trade, and wages. J. Int. Econ. 2005, 65, 1-20. [CrossRef]

24. Rossi-Hansberg, E.; Garicano, L.; Antràs, P. Offshoring in a Knowledge Economy. Q. J. Econ. 2006, 121, 31-77. [CrossRef]

25. Costinot, A.; Vogel, J. Matching and Inequality in the World Economy. J. Polit. Econ. 2010, 118, 747-786. [CrossRef]

26. Helpman, E.; Itskhoki, O.; Redding, S. Inequality and Unemployment in a Global Economy. Econometrica 2010, 78, 1239-1283. [CrossRef]

27. Blanchard, E.; Willmann, G. Trade, education, and the shrinking middle class. J. Int. Econ. 2016, 99, $263-278$. [CrossRef]

28. Jung, J. Technology, skill, and growth in a global economy. Econ. Theory 2019, 68, 609-641. [CrossRef] 
29. Jung, J. Introducing Roy-like worker assignment into computable general equilibrium models. Appl. Econ. Lett. 2020, 27, 503-510. [CrossRef]

30. Brunetti, A.; Weder, B. Investment and institutional uncertainty: A comparative study of different uncertainty measures. Weltwirtsch. Arch. 1998, 134, 513-533. [CrossRef]

31. Julio, B.; Yook, Y. Policy uncertainty, irreversibility, and cross-border flows of capital. J. Int. Econ. 2016, 103, 13-26. [CrossRef]

32. Dixit, A. Entry and Exit Decisions under Uncertainty. J. Polit. Econ. 1989, 97, 620-638. [CrossRef]

33. Dixit, A. Investment and Hysteresis. J. Econ. Perspect. 1992, 6, 107-132. [CrossRef]

34. Dixit, A. Irreversible investment with uncertainty and scale economies. J. Econ. Dyn. Control 1995, 19, 327-350. [CrossRef]

35. Pindyck, R.S. Irreversible Investment, Capacity Choice, and the Value of the Firm. Am. Econ. Rev. 1988, 78, 969-985. [CrossRef]

36. Pindyck, R.S. Irreversibility, Uncertainty, and Investment. J. Econ. Lit. 1991, 29, 1110-1148. [CrossRef]

37. Dixit, A.; Pindyck, R. Investment Under Uncertainty, 1st ed.; Princeton University Press: Princeton, NJ, USA, 1994.

38. Yi, K.M. Can Vertical Specialization Explain the Growth of World Trade? J. Polit. Econ. 2003, 111, 52-102. [CrossRef]

39. Markusen, J. Multinational Firms and the Theory of International Trade, 1st ed.; MIT Press: Cambridge, MA, USA, 2002.

40. Girma, S. Absorptive Capacity and Productivity Spillovers from FDI: A Threshold Regression Analysis. Oxf. Bull. Econ. Stat. 2005, 67, 281-306. [CrossRef]

41. Ubeda, F.; Pérez-Hernández, F. Absorptive Capacity and Geographical Distance Two Mediating Factors of FDI Spillovers: A Threshold Regression Analysis for Spanish Firms. J. Ind. Compet. Trade 2017, 17, 1-28. [CrossRef]

42. Pearce, D.W.; Barbier, E.B.; Markandya, A. Blueprint for a Green Economy, 1st ed.; Earthscan Publications Ltd.: London, UK, 1989.

43. World Bank. Expanding the Measure of Wealth: Indicators of Environmentally Sustainable Development; World Bank: Washington, DC, USA, 1997.

(C) 2020 by the author. Licensee MDPI, Basel, Switzerland. This article is an open access article distributed under the terms and conditions of the Creative Commons Attribution (CC BY) license (http://creativecommons.org/licenses/by/4.0/). 